\title{
A SPECIFIC RADIOIMMUNOASSAY FOR ANDROSTENEDIONE WITH REDUCED BRIDGE-BINDING
}

Gerald D. Nordblom ${ }^{1}$, Raymond E. Counsell ${ }^{2}$ and Barry G. England ${ }^{1}$

1 Department of Pathology, Oniversity of Michigan, Ann Arbor, MI 48109

2 Department of Pharmacology, University of Michigan, Ann Arbor, MI 48109

Received 3-15-85.

ABSTRACT

Antibody used in a steroid radioimmunoassay raised against a steroid hapten-carrier proteln conjugate may recognize both the hapten and the chemical bridge to the protein. Use of the same bridge in the radioisotopic label may lead to higher affinity binding to the label than to the native steroid. Inhibition curves under these conditions are shallow and generally not acceptable for radioimmunoassay procedures. We have developed a radioimmunoassay for androstenedione that employs different bridges at the $11 \beta$ position of the sterold for the protein conjugate and label. The resulting assay has greatly reduced bridgebinding, has an acceptable slope for the standard curve and is very specific as evidenced by low crossreactivies to other steroids.

\section{INTRODUCT ION}

To develop a radioimmunoassay (RIA) for measuring steroids, antibodies for the assay are produced using a steroid hapten-carrier protein conjugate. The resulting antibodies often recognize and demonstrate high affinity binding to both the sterold and the chemical bridge through which the hapten was attached to the carrier protein. This phenomena is referred to as bridge-binding (1-8). Use of ${ }^{125} \mathrm{I}$ as the radionuclide to produce a labeled trace for the RIA requires that the lodinated functional group, phenol or imidazole, be attached to the sterold with a chemical bridge. However, if the label-bridge is homologous to the conjugate-bridge, the antibodies will have a higher affinity for the label than the native steroid. Consequently, the amount of steroid required to displace the radiolodinated steroid will be so great that the standard curve will shift to the right resulting in a substantial loss of sensitivity. In addition, the slope of the curve will be very shallow causing a loss of precision. 
Recently we reported (1) on a procedure for reducing bridgebinding in a RIA for androstenedione (9). By using both a succinyl ester linkage $\left(-\mathrm{O}_{2} \mathrm{CCH}_{2} \mathrm{CH}_{2} \mathrm{CO}_{2}\right.$-sterotd) and an ether linkage ( $-\mathrm{NHCOCH}_{2} \mathrm{O}$ steroid) attached to the 19 position of androstenedione, we were able to obtain a very sensitive and precise RIA. Unfortunately, the antisera, which was produced in sheep, was not very specific. The assay had a high crossreactivity towards closely related steroids, such as 5 o-androstanedione, dehydroepiandrosterone and androsterone. Later, Rao et al reported (10) a RIA using a tritiated label and rabbit antibody against a bovine serum albumin-androstenedione conjugate (BSA-NHCOCH 2 0-19-androstenedione) which was structurally identical to one that we had used (1). Although their rabbit antibody was more specific than the sheep antisera, it exhibited high nonspecificity to $5 \alpha$-androstanedione and crossreactivity of about $2 \%$ or more to testosterone, dehydroepiandrosterone and androsterone.

We wish to report a RIA that employs sheep antibody against androstenedione linked to BSA with an ether bridge at the $11 \mathrm{~B}$ position of the steroid (BSA-NHCOCH $20-11 \beta$-androstenedione) and a label that has an ester bridge ( ${ }^{125} \mathrm{I}$-phenol- $\mathrm{CH}_{2} \mathrm{CO}_{2}-11 \mathrm{\beta}$-androstenedione). The resulting assay is very sensitive and precise. In addition, the crossreactivities of the antibody against testosterone, androsterone and dehydroepiandrosterone are at least ten-fold less than those reported by Rao et aI (10).

\section{MATERIALS}

$\mathrm{Na}\left[{ }^{125} \mathrm{I}\right]$ (carrier free) was obtalned from New England Nuclear. 11 B-hydroxyandrostenedione, 1-ethy 1-3-(3-dimethylaminopropy1)carbodilmide, dehydroepiandrosterone, testosterone, 5a-dihydrotestosterone, pigskin gelatin, bovine serum albumin and merthiolate (thimerosal) were obtained from Sigma Chemical Co. Ethyl diazoacetate, p-toluenesulfonic acid and p-hydroxyphenylacetic acid were purchased from Aldrich Chemical Co. ChIoramine-T and sodium metabisulfite were from J.T. Baker Co. Androstenedione, androsterone, $5 \alpha$-androstenedione, progesterone and estradiol-17B were purchased from Steraloids Inc., Wilton, $\mathrm{N} . \mathrm{H}$. $\mathrm{RhCl}_{3} \cdot 3 \mathrm{H}_{2} \mathrm{O}$ was from Ventron Corporation and HPLC grade acetonitrile was from Burdick \& Jackson Laboratories, Muskegon, MI. Other soivents were analytical grade. Steroids used as RIA standards and crossreactants were recrystallized.

\section{SYNTHESES}

The syntheses of the conjugate and radioiodinated label used in this study are outlined in figure 1. Melting points were determined 
in capillary tubes in a Thomas-Hoover apparatus and were corrected. Spectral analyses were obtained with the following instruments: IR, Perkin-Elmer 281; NMR, Varian EM-360; and OV, Cary 219.<smiles>CC(C)(C)NC(=O)COC1CC2C(=O)CCC2C2CCC3=CC(=O)CCC34CCC(=O)CC43CCC(=O)C=C3CCC12</smiles>

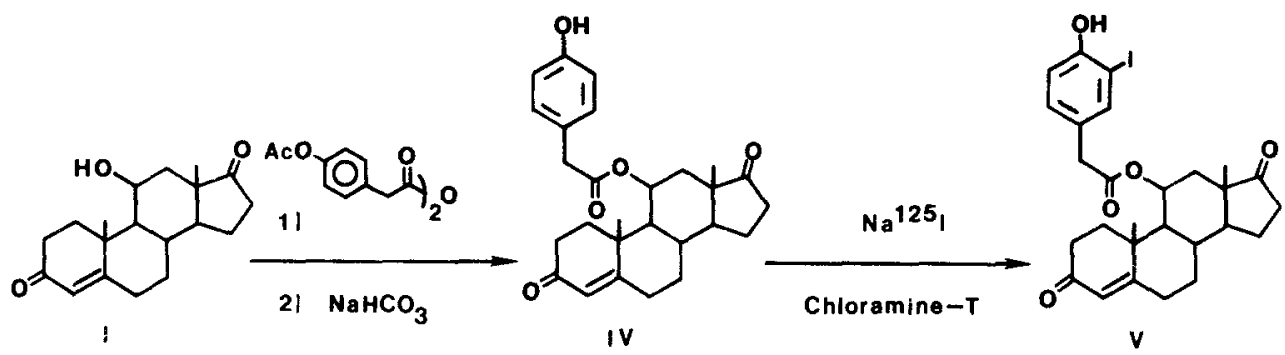

Figure 1. Synthetic Schemes

$11 \beta=$ (Carboxymethoxy)-4-androstene-3.17-dione (II). 11k-hydroxyandrostenedione (250 $\mathrm{mg}, 0.84 \mathrm{mmol}$ ) was dissolved in dry benzene ( 40 $\mathrm{mL})$. The catalyst $\mathrm{Rh}_{2}\left(\mathrm{O}_{2} \mathrm{CCH}_{3}\right)_{4}(3 \mathrm{mg})$, prepared from $\mathrm{RhCl}_{3} \cdot \mathrm{H}_{2} \mathrm{O}(11)$, was then added. Ethyl diazdacetate $(1.09 \mathrm{gm}, 9.51 \mathrm{mmol})$ was added dropwise to the steroid solution. Additional ethyl diazoacetate (2.18 $\mathrm{gm}, 19.02 \mathrm{mmol}$ ) was added $6 \mathrm{hr}$ later, and the reaction stirred at room temperature overnight. The reaction mixture was poured into $\mathrm{H}_{2} \mathrm{O}(100$ $\mathrm{mL})$ and extracted five times with $\mathrm{CHCl}_{3}(50 \mathrm{~mL})$. The combined organic layer was drled with $\mathrm{Na}_{2} \mathrm{SO}_{4}$ and evaporated in vacuo yielding a yellow oil. The oil was chromatographed on a $1.5 \times 30 \mathrm{~cm}$ silica gel column using a $\mathrm{O}$ to $2 \% \mathrm{CH}_{3} \mathrm{OH}$ gradient in $\mathrm{CHCl}_{3}$ for elution. A second chromatography step on $31.5 \times 30 \mathrm{~cm}$ silica gel column with a 0 to $20 \%$ ethyl acetate gradient yielded $11 \beta$-(ethylcarboxymethoxy)-4-androstene-3,17dione as a clear oil $(120 \mathrm{mg}, 37.4 \%)$. IR $\left(\mathrm{CHCI}_{3}\right), \underline{\max } 1740$ and 1668 $\mathrm{cm}^{-1}: \mathrm{NMR}\left(\mathrm{CDCl}_{3}\right), \delta 1.10\left(\mathrm{~s}, 3 \mathrm{H}, 18-\mathrm{CH}_{3}\right), 1.26^{3}(\mathrm{t} \mathrm{J}=8.0 \mathrm{cps}, 3 \mathrm{H}$, $\left.-\mathrm{OCH}_{2} \mathrm{CH}_{3}\right), 1.52\left(\mathrm{~s}, 3 \mathrm{H}, 19-\mathrm{CH}_{3}\right), 4.10^{-3}\left(\mathrm{~m}, 5 \mathrm{H}, 11 \mathrm{~B}-\mathrm{OCH}_{2} \mathrm{CO}_{2},-\mathrm{OCH} 2 \mathrm{CH} 3\right.$, $11 \alpha-\underline{\mathrm{H}}), 35.72(\mathrm{~s}, 1 \mathrm{H}, 4-\mathrm{H})$. Anal. Calc. $\mathrm{C}_{23} \mathrm{H}_{32} \mathrm{O}_{5}: \mathrm{C}, 71,11 ; \mathrm{H}, 8 \cdot 30$. Found: C,71.15;H,8.26. 
The ethylcarboxymethoxy derivative from above (135 mg, $0.346 \mathrm{mmol}$ ) was dissolved in $\mathrm{CH}_{3} \mathrm{OH}(10 \mathrm{~mL})$. $\mathrm{KOH}(6.4 \mathrm{~mL}$ of $0.1 \mathrm{M}, 0.70 \mathrm{mmol})$ was added dropwise at $10^{\circ} \mathrm{C}$. The reaction mixture was then poured into saturated $\mathrm{NaCl}$ solution ( $200 \mathrm{~mL}$ ) and made slightly acidic with $1 \underline{\mathrm{N}}$ $\mathrm{HCl}$. The resulting aqueous mixture was extracted six times with $\mathrm{CHCl}$ $(10 \mathrm{~mL})$. The combined organic phase was dried as above and evaporated In vacuo yielding $11 \beta$-(carboxymethoxy)-androstene-3,17-dione (II) as a clear oil $(120 \mathrm{mg}, 96 \%)$. IR $\left(\mathrm{CHCl}_{3}\right), \operatorname{Vmax} 3400,1739$ and $1668 \mathrm{~cm}^{-1}$ : NMR $\left(\mathrm{CDCl}_{3}\right), \delta 1.07\left(\mathrm{~s}, 3 \mathrm{H}, 18-\mathrm{CH}_{3}\right), 31.50\left(\mathrm{~s}, 3 \mathrm{H}, 19-\mathrm{CH}_{3}\right), 4.05(\mathrm{~s}, 2 \mathrm{H}$, $\left.-\mathrm{OCH}_{2} \mathrm{CO}_{2} \mathrm{H}\right)^{3}, 4.18(\mathrm{~m}, 1 \mathrm{H}, 11 \alpha-\mathrm{H}), 5.75(\mathrm{~s}, 1 \mathrm{H}, 4-\mathrm{H}), 6.00$ (broad $\mathrm{s}, 1 \mathrm{H}$, -CO2H, exchanged with $\left.\mathrm{D}_{2} \mathrm{O}\right)$.

$11 \beta=[\mathrm{N}-$-(Bovine serum albumin)-amidocarboxymethoxy]-4-androstene-3,1]= dione (III), The carboxymethoxy derivative II (100 mg, $0.28 \mathrm{mmol})$ was dissolved in dimethyl formamide $(10 \mathrm{~mL})$ and $\mathrm{H}_{2} \mathrm{O}(4 \mathrm{~mL})$. 1-Ethyl3-(3-dimethylaminopropyl)-carbodiimide (EDAC) (100 mg, $1.92 \mathrm{mmol}$ was added, and the mixture stirred for $30 \mathrm{~min}$. Bovine serum albumin (BSA) (200 mg) dissolved in phosphate buffer $(0.01 \mathrm{M}, \mathrm{pH} 7.8,20 \mathrm{~mL})$ was added dropwise to the steroid solution which was stirred two days at ambient temperature in the dark. The solution was dialyzed against $0.05 \mathrm{M} \mathrm{NaHCO}_{3}(2 \times 2 \mathrm{~L})$ and $\mathrm{H}_{2} \mathrm{O}(4 \times 2 \mathrm{~L})$ and lyophilized. The molar ratio of the steroid to protein was found to be 15.0 by spectral analysis (1).

$11 B=(p-H y d r o x y p h e n y l a c e t o x y)-4$-androstene-3,17-dione (IV), p-Toluenesulfonic acid $(160 \mathrm{mg}, 0.842 \mathrm{mmol})$ was dissolved in benzene ( $30 \mathrm{~mL}$ ), and the mixture refluxed with a Dean-stark apparatus for $3 \mathrm{hr}$ to remove $\mathrm{H}_{2} \mathrm{O}$. $11 \mathrm{~B}$-Hydroxyandrostenedione (100 $\left.\mathrm{mg}, 0.33 \mathrm{mmol}\right)$ and p-acetoxyphenylacetic anhydride (1) $(200 \mathrm{mg}, 0.54 \mathrm{mmol})$ were added to the benzene solution and the resulting mixture was refluxed for 10 additional min, cooled to room temperature and stirred $48 \mathrm{hr}$. The reaction mixture was poured into $\mathrm{H}_{2} \mathrm{O}(100 \mathrm{~mL})$ and extracted six times with $\mathrm{CHCl}_{3}(30 \mathrm{~mL})$. The combined organic layer was dried as before and evaporated in vacuo yielding a clear oil. The oil was dissolved in methanol ( $5 \mathrm{~mL}), 4$ drops of saturated $\mathrm{NaHCO}_{3}$ were added, and the mixture stirred fo $1.5 \mathrm{hr}$. The $\mathrm{pH}$ of the solution was adjusted to 2.0 with $0.5 \underline{\mathrm{N}} \mathrm{HCl}$ and extracted five times with $\mathrm{CHCl}_{3}(15 \mathrm{~mL})$. The chloroform layer was washed twice with $\mathrm{H}_{2} \mathrm{O}(10 \mathrm{~mL})$ and dried. Removal of the solvent left a yellow oil that was purified on a $1.5 \times 30 \mathrm{~cm}$ silica gel column. Elution with benzene/ethyl acetate (4/1) yielded a clear oll. Recrystallization from acetone/hexane produced IV as a white solid ( $84 \mathrm{mg} 58 \%$ ) mp $154-155^{\circ} \mathrm{C}$. IR $\left(\mathrm{CH}_{2} \mathrm{Cl}_{2}\right)$, V $\max 3600,1730$, white solid ( $84 \mathrm{mg}^{-58 \%)} \mathrm{mp} 154-155 \mathrm{~cm}^{-1}$ : NMR $\left(\mathrm{CDCl}_{3}\right), \delta 0.78\left(\mathrm{~s}, 3 \mathrm{H}_{2}, 18-\mathrm{CH}_{3}\right), 1.14(\mathrm{~s}, 3 \mathrm{H}$, 1670 and $1525 \mathrm{~cm}:$ NMR $\left(\mathrm{CDCl}_{3}\right), \delta 0.78(\mathrm{~s}, 3 \mathrm{H}, 1 \mathrm{H}-1 \mathrm{CH}-\mathrm{H}), 5.71(\mathrm{~s}, 1 \mathrm{H}$, $4-\underline{H}), 6.76$ and 7.11 (dd $\mathrm{J}=10.5 \mathrm{cps}, 4 \mathrm{H}$, pheny $1-\underline{\mathrm{H}}$ ), 7.80 '(broad s, $1 \mathrm{H}$, phenyl-OH, exchanged with $\left.\mathrm{D}_{2} \mathrm{O}\right)$. Anal. Calc. $\mathrm{C}_{27} \mathrm{H}_{32} \mathrm{O}_{5}: \mathrm{C}, 74.29$; $\mathrm{H}$, 7.39. Found: $\mathrm{C}, 74.41 ; \mathrm{H}, 7.46$.

Radiolodination of IV. The p-hydroxyphenyl derivative IV $(2.0 \mathrm{ug}$, $4.58 \mathrm{nmol}$ ) in ethanol ( $2 \mathrm{uL}$ ) was placed in a $1 \mathrm{~mL}$ vial fitted with a multi-dose septum. Phosphate buffer $(0.5 \mathrm{M}, \mathrm{pH} 7.4,40 \mathrm{uL})$ and
aqueous $\mathrm{Na}[25 \mathrm{I}](4.0 \mathrm{mCi}, 11.2 \mathrm{uL})$ were added. The iodination was initiated by the addition of chloramine-T (20 ug, $106.5 \mathrm{nmol}$ ) in phosphate buffer $(0.05 \mathrm{M}, \mathrm{pH} 7.4,30 \mathrm{uL}$ ) (buffer A). After shaking at 
ambient temperature for $1 \mathrm{~min}$, the reaction was quenched by the addition of sodium metabisulfite (10 ug, $52.5 \mathrm{nmol}$ ) in buffer $A$ (20 uL). Purification of the radioiodinated steroid was done by HPLC. The entire reaction mixture was injected onto an Altech 600-RPA C reverse phase column using a Rheodyne injector fitted with a 100 uf loop. A Spectro Physics SP8700 pump provided the following mobile phase at a flow rate of $1 \mathrm{~mL} / \mathrm{min}$ : 0 to $5 \mathrm{~min}$, an isocratic mixture of $20 \%$ acetonitrile in $0.05 \mathrm{M}$ potassium formate buffer, $\mathrm{pH} 4.0 ; 5$ to 80 min, a 20 to $60 \%$ gradient of acetonitrile in the formate buffer. The eluted material was collected in a Gilson FC-80 Fraction Collector ( 1 min fractions), and the radioactivity was quantitated with a gamma counter. Both a monoiodinated (eluting at $65 \mathrm{~min}$ ) and a diiodinated derivative $(77 \mathrm{~min})$ of the steroid were isolated. The estimated specific activity (12) of the two labels were found to be $3.3 \mathrm{mCl} / \mathrm{l}: \mathrm{z}$ and $5.4 \mathrm{mCl} / \mathrm{ug}$, respectively. The monolodinated label, which was used in the RIA, had a maximal binding (active fraction) of $98 \%$ in the presence of exess antibody.

\section{METHODS}

Antibody Production, Antibody against the steroid-BSA conjugate III was raised in five Suffolk ewes. Two milligrams of the conjugate in Freund's complete adjuvant $(1.0 \mathrm{~mL})$ was injected intradermally at multiple sites on the flanks of each animal. Booster injections of $1.0 \mathrm{mg}$ in incomplete Fruend's adjuvant $(1.0 \mathrm{~mL})$ were given at weeks 4 and 8 . Bleedings were taken at weeks 10 and 11 and the highest titers (dilution of serum needed to bind $50 \%$ of the label) were found at week 11. Serum from sheep \#95, which had the best specificity, was used for the RIA.

Radioimmunoassaye The radioimmunoassay was run as described previously (1) using a 1/50,000 dilution of antisera and 40,000 $\mathrm{cpm} /$ tube of label. Crossreactivity studies were done using the method of Thorneycroft et al (13).

\section{RESULTS AND DISCUSSION}

It was obvious from our previous paper (1) that bridge-binding could be significantly reduced in a RIA for androstenedione by employing heterologous bridges when synthesizing the immunogenic steroidcarrier protein conjugate and the ${ }^{125}$ I-steroid label. It was also apparent that use of the 19 position of the steroid for functionalization introduced problems of specificity. Consequently, we chose to use the same type of Iinkages but at a different position, namely, the $11 \beta$ position of androstenedione. When antibody against an etherlinked BSA conjugate ( $\mathrm{BSA}-\mathrm{NHCOCH}_{2} \mathrm{O}-11 \beta$-androstenedione) was used in conjunction with an ester-linked label ( ${ }^{125} \mathrm{I}$-phenol- $\mathrm{CH}_{2} \mathrm{CO}_{2}-11_{\beta}$-androstenedione), we obtained a standard curve with a $50 \%$ inhibition point 
of $104 \mathrm{pg} /$ tube and a slope of -1.73 . The $50 \%$ point was somewhat higher than that reported previously (1) (104 pg vs. 15 or 76 pg). However, the actual limit of detection (14) is certainly adequate for routine use (200 femtograms ( $f g$ )/assay tube). The slope of -1.73 was less than the ideal -2.303 for a $\log 1 \mathrm{t}-\mathrm{log}$ curve but provides a workable assay.

The most obvious improvement was in assay specificity as can be seen in table 1 which compares the crossreactivity of our current assay using antibody against the $11 \beta$-conjugate to the crossreactivities we reported (1) and those Rao et al reported (10) using antibodies to the 19-conjugate.

Table 1

\section{qCrossreactivity}

Steroid Anti-11 Anti-19 (1) Rao et al (10)

Androstenedione

$5 \alpha$-Androstanedione

Testosterone

100.0

100.0

61.7

100.0

0.06

0.05

30.38

0.17

0.21

0.04

2.50

5a-Dihydrotestosterone

10.0

0.14

0.26

48.1

1.55

2.54

Androsterone

Progesterone

0.007

0.03

1.93

0.55

Estradiol-17\%

0.08

0.08

The crossreactivity of the $11 \beta$-system to $5 \alpha$-androstanedione is 5.2\% vs. $61.7 \%$ and $30.38 \%$ for the two 19-systems. Antibodies to androgens, such as androstenedione and testosterone, usually cannot differentiate very well between the 4-ene and $5 \alpha$ - forms of the steroids (15-18). The best evidence for improved specificity lies in the comparison of the crossreactivities of dehydroepiandrosterone and androsterone. We obtained $0.21 \%$ and $0.14 \%$, respectively, compared-to $10.0 \%$ and $48.1 \%$ for the anti-19-conjugate (1). Although Rao et al (10) reported antisera (rabbit) to the 19-conjugate with higher specificity than we described (sheep) using the same immunogen (1), the rabbit antibodies are at least 10 -fold less specific than the anti-118-conjugate antibodies. In addition, the anti-11 $\beta$-antiserum also has lower crossreactivity to testosterone and $5 \alpha$-dihydrotestosterone than that reported for the rabbit anti-19-conjugate (10). 
The crossreactivity of anti-androstenedione antisera to testosterone and dehydroepiandrosterone is critical since they are present in male human serum samples at concentrations greater than or equal to the amount of androstenedione (19) and would interfere in a RIA.

In conclusion, by using the heterologous bridges we described previously (1), a sensitive and precise steroid radioimmunoassay can be developed. This is evidenced by the assay limit of detection of $200 \mathrm{fg} /$ tube and slope of the inhibition curve of -1.73 . In addition, one can produce very specific antibodies by using the $11 \beta$ position of androstenedione for attachment of the carrier-protein and labeled functional groups.

\section{REFERENCES}

1. Nordblom, G.D., Webb, R., Counsell, R.E. and England, B.G., STEROIDS, 38, 161 (1981).

2. Painter, K. and Niswender, G.D., in: Methods of Hormone Radioimmunoassay (Jaffe, B. and Behrman, H.R., Editors) Academic Press, N.Y. (1979), p 727 .

3. Corrie, J.E.T. and Hunter, W.M., METHODS ENZYMOL, 73, 79 (1981).

4. Hunter, W.M., Nars, P.W. and Rutherford, F.J. in: Eifth Tenovus Workshop, Steroid Immunoassay (Cameron, E.H.D. and Griffiths, Editors) Alpha Omega, Wales, U.K. (1975), p 141.

5. Corrie, J.E.T., Hunter, W.M. and Macpherson, J.S., CLIN. CHEM., 27, 594 (1981).

6. Corrie, J.E.T., Ratcliffe, W.A. and Macpherson, J.S., STEROIDS, 38, 709 (1981):

7. Allen, R.M. and Redshaw, M.R., STEROIDS, 32, 467 (1978).

8. Nordblom, G.D. Counsell, R.E. and England, B.G., LIGAND QUARTERLY, 2. 34, (1979).

9. Trivial steroid names used are: androstenedione, 4-androstene3,17-dione; $5 \alpha$-androstanedione, 5 -androstane-3,17-dione; dehydroepiandrosterone, 3ß-hydroxy-5-androsten-17-one; androsterone, $3 \alpha$-hydroxy-5 $\alpha$-androstan-17-one; testosterone, 17 $\beta$-hydroxy-4-

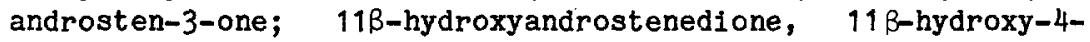
androstene-3,17-dione; $5 \alpha$-dihydrotestosterone, 17 $\beta$-hydroxy-5 $\alpha-$ androstan-3-one; progesterone, 4-pregnene-3,20-dione; estradiol$17 \beta, 1,3,5,(10)$-estratriene-3,17 $\beta$-diol.

10. Rao, P.N., Damodaran, K.M., Moore, P.H., Desjardins, C. and Garza, G., J. STEROID BIOCHEM., 17, 523 (1982).

11. Legzdins, P., Mitchell, R.W., Rempel, G.L., Ruddick, J.D. and Wilkinson, G., J. CHEM. SOC. A, 3322 (1970).

12. Morris, B.J., CLINICA CHEMICA ACTA, 73, 213 (1976).

13. Thorneycroft, I.H., Caldwell, B.V., Abraham, G.E., Tilson, S.A. and Scaramuzzi, R.J., in: Research on Steroids. (Finkelstein, M., Conti, C., Klopper, A. and Cassano, C., Editors) Permagon Press, Oxford, Vol. 4 (1970), p 205. 
14. The computer program we used defined the limit of detection as $100 \%$ binding less two standard deviations of the assay or $100 \%$ binding less two standard deviations of the buffer control, whichever had the lower mean variance ratio.

15. Bermudez, J.A., Coronado, V., Mijares, A., Leon, C., Velaquez, A., Nobel, P. and Mateos, J.L., J. STEROID BIOCHEM., $6,28 \overline{3}$ (1975).

16. Milewich, L., Gomez-Sanchez, C., Macdonald, P.C. and Sitteri, P.R., J. STEROID BIOCHEM., 6, 1381 (1975).

17. Parker, L.N., Grover, P.K. and Odell, W.D., STEROIDS, 29, 715 (1977).

18. Rao, P.N., Moore, P.H., Peterson, D.M. and Tcholakian, R.K., J. STEROID BIOCHEM. , 2, 539 (1978).

19. Counsell, R.E. and Brueggemeier, R., in: Burger's Medicinal. Chemistry, 4 th Ed., Part II (Wolff, M.F., Editor) John Wiley \& Sons, N.Y. (1979), pp 873-916. 